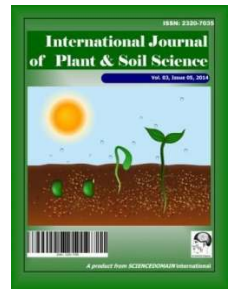

\title{
Assessment of the Suitability of Groundwater for Irrigation at Federal University of Agriculture Makurdi, Benue State
}

\author{
S. O. Odoemena ${ }^{1^{*}}$, O. G. Ogundeji $1^{1 *}$ and E. A. Igomu ${ }^{1 *}$ \\ ${ }^{1}$ Department of Soil Science, University of Agriculture, Makurdi, Benue State, Nigeria.
}

Authors' contributions

This work was carried out in collaboration between three authors. Author SOO designed the study, wrote the protocol, supervised the literature search and managed the analysis of the study. Author OGO collected the samples, performed the statistical analysis and wrote the first draft of the manuscript. Author EAI audited the presentation and made the final compilation of the work. All authors read and approved the final manuscript.

Article Information

DOI: $10.9734 /$ IJPSS/2017/34777

Editor(s):

(1) Kursat Korkmaz, Department of Soil Science and Plant Nutrition, Faculty of Agriculture, Ordu University, Turkey.

Reviewers:

(1) C. R.Ramakrishnaiah, Visvesvaraya Technological University, India.

(2) Olumuyiwa Idowu Ojo, University of South Africa, South Africa.

Complete Peer review History: http://www.sciencedomain.org/review-history/20061

Original Research Article

Received $10^{\text {th }}$ June 2017

Accepted $11^{\text {th }}$ July 2017

Published $15^{\text {th }}$ July 2017

\begin{abstract}
Irrigation water suitability assessment plays an imperative role for sustainable utilization of scarce physical land resources. The study was aimed at assessing the suitability of groundwater quality for irrigation purpose at the Federal University of Agriculture, Makurdi. Random sampling techniques were utilized in the selection of samples of groundwater. Accordingly, five groundwater samples were collected from five boreholes for chemical analysis. The groundwater samples were analyzed for $\mathrm{Ca}^{2+}, \mathrm{Mg}^{2+}, \mathrm{K}^{+}, \mathrm{Na}^{+}, \mathrm{CO}_{3}{ }^{2-}, \mathrm{HCO}_{3}{ }^{-}, \mathrm{Cl}^{-}, \mathrm{SO}_{4}{ }^{2-}$, and $\mathrm{NO}_{3}{ }^{-}$besides $\mathrm{pH}$ and electrical conductivity (EC). Also, the Sodium Adsorption Ratio (SAR) for the groundwater samples and Exchangeable Sodium Percentage (ESP) for the soil samples were computed. Out of the analyzed 5 groundwater samples, 2 showed EC values below 250 and the remaining between 750 and $1161 \mathrm{dS} / \mathrm{m}$, and $\mathrm{pH}$ values ranged from 6.3 to 7.6. Chloride ion concentrations in groundwater ranged from 64 to 78 $\mathrm{mg} / \mathrm{l}$; bicarbonate $\left(\mathrm{HCO}_{3}{ }^{-}\right)$values ranged from 0.18 to $0.23(\mathrm{mg} / \mathrm{l})$; and nitrate $(\mathrm{NO} 3-\mathrm{N})$ values were below $5 \mathrm{mg} / \mathrm{l}$ except in one sample that had $5.87 \mathrm{mg} / \mathrm{l}$ as its value. The results indicated that
\end{abstract}

*Corresponding author: E-mail: odoemenasimon@gmail.com, igomumajor@gmail.com; 
the groundwater in general was suitable for irrigation purpose. However, in order to achieve and sustain full yield potentials for a long period of time, and to avoid increase in salinity and avoid the occurrence of sodicity and toxicity hazard in future, proper irrigation scheme is required in the form of crop selection, fertilizer usage and suitable alternative management.

Keywords: Agriculture; assessment; groundwater; irrigation; land; Makurdi; suitability.

\section{INTRODUCTION}

Globally, irrigated agriculture is the largest abstractor and predominant consumer of groundwater resources, with important groundwater dependent agro-economies having widely evolved [1].

Use of land and water resources for the development of irrigation facilities could lead to substantial increase in food production in many parts of the world. Proper use of land depends on the suitability or capability of land for specific purposes [2]. Thus, to enhance food security at national as well as household level, improvement and expansion of irrigated agriculture must be seriously considered. Irrigation is one of the methods used to increase food production in arid and semi-arid regions. It can enhance food security, promote economic growth and sustainable development, create employment opportunities, improve living conditions of smallscale farmers which, contribute to poverty reduction. Furthermore, it increases subsurface water levels and recharges groundwater. On the other hand, if irrigation is not properly managed, it can have adverse effects on the environment and the users. Therefore, farmers are advised to dig hand dug wells in their farm plot and utilize the groundwater for irrigation [3].

An understanding of the quality of water used for irrigation and its potentials to cause negative impact on crop growth is essential to avoid yield loss and optimize food production. The geochemical investigation of groundwater allows us to obtain important information on chemical weathering of rocks [4]. Quality of the water was part of the ecological issues required for consideration at the onset. Knowledge of irrigation water quality is critical to understanding what management changes are necessary for long-term productivity $[5,6,7]$. Beside, irrigated agricultural crops need good quality water. However, sustainable utilization of groundwater as a source of water for irrigation requires quality and quantity fitness of the groundwater for this purpose. This study addressed one of these gaps; which is determination of the suitability of the groundwater for irrigation purpose. Therefore, the main center of attention of this study was to assess the groundwater suitability for irrigation in Federal University of Agriculture Makurdi.

The availability of groundwater depends primarily on the geology. Groundwater is stored within the pore spaces and fractures in rocks. Where the pores or fractures are interconnected, groundwater can flow easily and the rocks are said to be permeable. The availability of groundwater also depends to a certain extent on the volume and intensity of rainfall since groundwater responds slowly to changes in the amount of rainfall, the impacts of drought are often buffered [8]. In areas with a long dry season, groundwater is still very available when sources such as rivers and streams have run dry. Groundwater is generally microbiologically uncontaminated and to a certain extent naturally protected from pollution. The resource is relatively cheap to develop, since large surface reservoirs are not required and water sources can usually be developed close to the demand [9].

Development of improved techniques for agricultural production is the main mandate of University of Agriculture Makurdi, which necessitated the need to determine the quality of groundwater within the University environment for irrigation purpose since such source of water is required during dry season farming.

\section{MATERIALS AND METHODS}

\subsection{The Study Area}

The study was conducted at Federal University of Agriculture, Makurdi. The University lies northeast of Makurdi town, which is between latitude $7.450 \mathrm{~N}$ and $7.500 \mathrm{~N}$ and longitude 8.000E and 9.000E. Makurdi is in a strategic position in the agricultural map of Nigeria, producing a wide range of both annual and perennial crops such as yam, maize, rice, sorghum, groundnut, soybean, cowpea, citrus, mangoes, and a variety of vegetables: one of the factors responsible for this wide range of crops is the favourable climate condition [10]. 
Makurdi has tropical climate conditions with distinct wet and dry seasons. The dry season starts from November to March while the rainy season starts from April to October. In the past, Benue state experienced a bimodal rainfall distribution pattern with one peak in July and another in September. Recent meteorological data point to unimodal pattern with the single peak in August. The mean annual rainfall for Benue state varies between 1000 and $1600 \mathrm{~mm}$.

The mean minimum air temperature of Makurdi was 16.20 to $17.20^{\circ} \mathrm{C}$ during the period of harmattan (December to February). The mean maximum air temperature was $37.7^{\circ} \mathrm{C}$ in March prior to the onset of rains. The slope of the area is 0 to $5 \%$ and the mean elevation above sea level was about $93 \mathrm{~m} \mathrm{[11].}$

\subsection{Data Collection}

To assess the suitability of the groundwater for irrigation purpose, the methods employed comprised field and laboratory work. Extensive work was carried out by collecting pertinent primary data of the area in the field and secondary data from different laboratories such as the Meteorological station. Collection, analyses and interpretation of topographical, hydrological, meteorological, soil, geological and hydro geological data, geological and hydro geological logs and other secondary data were done at the office level.

Five groundwater samples were selected randomly from the different boreholes for chemical analyses.

The following materials were used during the study:

\subsubsection{Plastic containers}

The plastic containers were used to collect water samples for laboratory analysis.

\subsubsection{Measuring cylinder}

Measuring cylinder was used to measure the volume of water used in the laboratory.

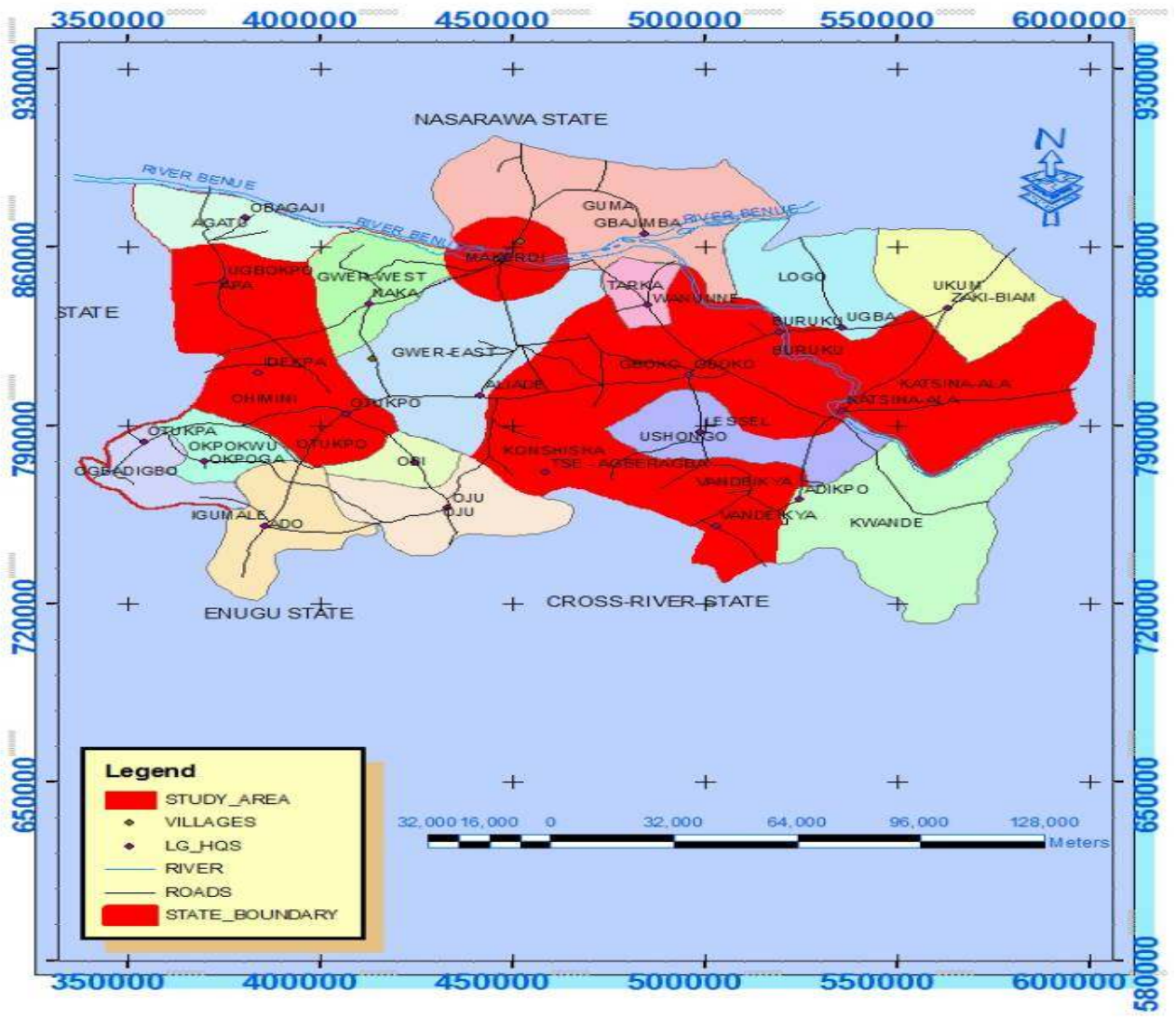

Fig. 1. Map of Benue State, Nigeria 


\subsubsection{Conductivity and $\mathrm{pH}$ meter}

Conductivity and $\mathrm{pH}$ meter was used to measure the $\mathrm{pH}$ and electrical conductivity $(\mathrm{EC})$.

\subsubsection{Flame photometer}

Flame photometer was used to determine the concentrations of ions.

\subsubsection{Spectrophotometer}

Spectrophotometer was used to analyze sulphates.

\subsection{Groundwater Development}

The investigated area was supplied mainly with groundwater from developed hand dug wells. The shallow, mostly unconfined and confined, aquifers in the thin alluvial covers and weathered and fractured upper parts of the rocks were exploited through these hand dug wells.

They supplied water daily for domestic use, irrigation and livestock consumption.

\subsubsection{Other sources of irrigation water in the study area}

Sources of water for irrigation within Federal University of Agriculture during the dry season were:

- Groundwater (from boreholes and wells)

- Existing streams at the early time of dry season

- Water pumped from the University's Water Works.

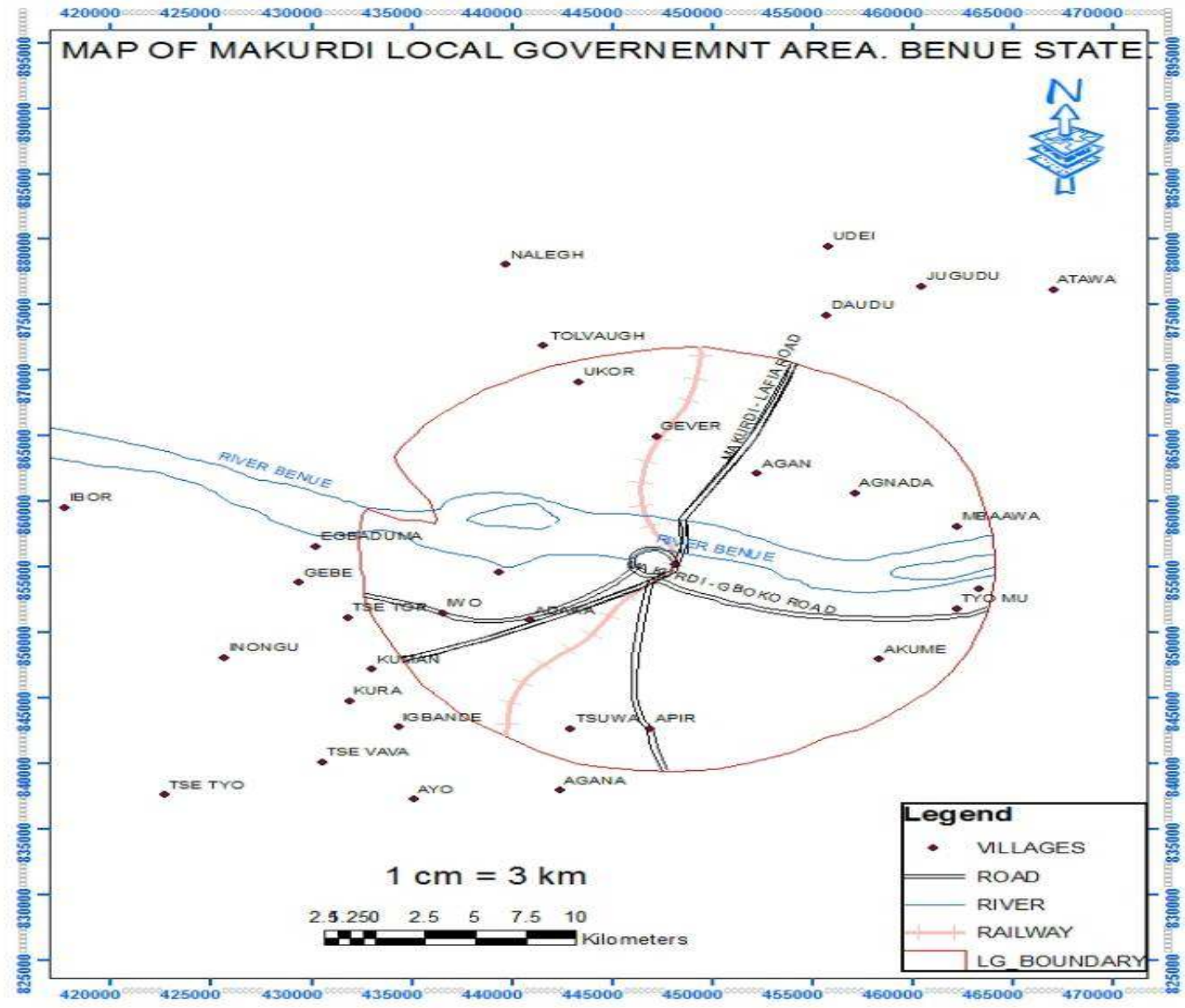

Fig. 2. Map of Makurdi local government area of Benue State 


\subsection{Groundwater Quality for Irrigation}

Nearly all water contains dissolved salts and two elements, many of which results from the natural weathering of the earth's surface. In addition, drainage water from irrigated lands and effluent from city sewage and industrial waste water can impact water quality in most irrigation situations. The primary water quality concern is salinity level, since salt can affect both the soil structure and crop yield. However, a number of trace elements are found in water which can limit its use for irrigation; generally, salt is though as ordinary table salt (sodium chloride). The quality of water for irrigation depends on the amount of sediments and the chemical constituents and also on nature of minerals and soil conditions through which water has passed. Numerous parameters are used to access salinity hazards and to determine appropriately;

- The total concentration of soluble salt.

- The relative proportion of sodium to other cations.

- The bicarbonate concentration as related to the concentration of calcium and magnesium.

- Concentration of potentially toxic elements.

Table 1. Kinds of salt found in irrigation water with chemical symbols and appropriate proportion of each salt

\begin{tabular}{|c|c|c|}
\hline Chemical name & Chemical symbol & Appropriate proportion \\
\hline Sodium chloride & $\mathrm{NaCl}$ & Moderately to large \\
\hline Sodium sulfate & $\mathrm{Na}_{2} \mathrm{SO}_{4}$ & Moderately to large \\
\hline Calcium chloride & $\mathrm{CaCl}_{2}$ & Moderate \\
\hline Calcium sulfate & $\mathrm{CaSO}_{4}$ & Moderate to small \\
\hline Magnesium chloride & $\mathrm{MgCl}_{2}$ & Moderate \\
\hline Magnesium sulfate & $\mathrm{MgSO}_{4}$ & Moderate to small \\
\hline Potassium chloride & $\mathrm{KCl}$ & Small \\
\hline Potassium sulfate & $\mathrm{K}_{2} \mathrm{SO}_{4}$ & Small \\
\hline Sodium bicarbonate & $\mathrm{NaCHO}$ & Small \\
\hline Calcium carbonate & $\mathrm{CaCO}_{3}$ & Very small \\
\hline Sodium carbonate & $\mathrm{Na}_{2} \mathrm{CO}_{3}$ & Trace to none \\
\hline Borate & $\mathrm{BO}^{3-}$ & Trace to none \\
\hline Nitrate & $\mathrm{NO}^{3-}$ & Small to none \\
\hline
\end{tabular}

Table 2. International standard for water quality usage

\begin{tabular}{lll}
\hline Parameter & Permissible $\mathbf{~ m g / L}$ & Excessive $\mathbf{~ m g / L}$ \\
\hline Magnesium $\left(\mathrm{Mg}^{2+}\right)$ & 50.0 & 150.0 \\
Calcium $\left(\mathrm{Ca}^{2+}\right)$ & 75.0 & 200.0 \\
Iron $\left(\mathrm{Fe}^{2+}\right)$ & 0.3 & 1.0 \\
Manganese $(\mathrm{Mn})$ & 0.1 & 0.5 \\
Cupper $\left(\mathrm{Cu}^{2+}\right)$ & 1.0 & 1.5 \\
Fluoride $(\mathrm{F})$ & 5.0 & 15.0 \\
Zinc $(\mathrm{Zn})$ & 5.0 & 15.0 \\
Chloride $(\mathrm{Cl})$ & 200.0 & 600.0 \\
Nitrate $(\mathrm{NO})$ & 50.0 & 100.0 \\
Sulphate $(\mathrm{SO} 4)$ & 200.0 & 400.0 \\
MgSO4+Na2SO4 & 500.0 & 1000.0 \\
Carbonate of Na,K,(as CaCO3) & 40.0 & 120.0 \\
Total soluble solid & 500.0 & 1500.0 \\
pH ranges (no unit) & $7.0-8.5$ & $6.5-9.2$ \\
\hline
\end{tabular}


Table 3. Recommended water classification based on electrical conductivity (EC)

\begin{tabular}{ll}
\hline Ecumhos/CM At $\mathbf{2 5}^{\circ} \mathbf{C}$ & Salinity assesment \\
\hline 250 & Low salinity \\
$250-750$ & Medium salinity \\
$>750-2250$ & High salinity \\
$>2250$ & Very high salinity \\
\hline
\end{tabular}

Table 4. Suitability of groundwater for irrigation

\begin{tabular}{|c|c|c|c|}
\hline \multicolumn{2}{|l|}{ Water class } & $\%$ of samples in pre-monsoon & $\%$ of samples in post-monsoon \\
\hline \multicolumn{4}{|l|}{$\mathrm{EC}(\mu \mathrm{S} / \mathrm{cm})$} \\
\hline \multicolumn{2}{|c|}{$<250$ Excellent } & 5.6 & 0.0 \\
\hline $250-750$ & Good & 33.33 & 16.7 \\
\hline $750-2000$ & Permissible & 38.90 & 44.4 \\
\hline $2000-3000$ & Doubtful & 16.70 & 16.7 \\
\hline$>3000$ & Unsuitable & 5.60 & 22.2 \\
\hline \multicolumn{4}{|c|}{ Alkalinity hazard (SAR) } \\
\hline$<10$ & Excellent & 89.00 & 89.0 \\
\hline $10-18$ & Good & 11.00 & 11.0 \\
\hline $18-26$ & Doubtful & - & - \\
\hline$>26$ & Unsuitable & - & - \\
\hline \multicolumn{4}{|c|}{ Percent sodium } \\
\hline$<20$ & Excellent & 27.78 & 27.78 \\
\hline $20-40$ & Good & 33.33 & 27.78 \\
\hline $40-60$ & Permissible & 11.11 & 22.22 \\
\hline $60-80$ & Doubtful & 22.22 & 22.22 \\
\hline$>80$ & Unsafe & 5.56 & 0.00 \\
\hline \multicolumn{4}{|c|}{ Residual sodium carbonate } \\
\hline$<1.25$ & Good & 77.80 & 89.00 \\
\hline $1.25-2.5$ & Doubtful & 0.00 & 11.00 \\
\hline$>2.5$ & Unsuitable & 22.20 & 0.00 \\
\hline
\end{tabular}

Table 5. Classification of groundwater on the basis of SAR, RSC and magnesium hazard

\begin{tabular}{llll}
\hline Classification scheme & Categories & Ranges & Percent of samples \\
\hline RSC & Good & $<1.25$ & 94.00 \\
& Medium & $1.25-25$ & 0.00 \\
& Bad & $>2.5$ & 6.00 \\
SAR & Excellent & $0-10$ & 0.00 \\
& Good & $10-18$ & 0.00 \\
\multirow{2}{*}{ Magnesium Hazard } & Fair & $18-26$ & 0.00 \\
& Poor & $>26.00$ & 0.00 \\
& Suitable & $<50.00$ & 81.00 \\
& Unsuitable & $>50.00$ & 19.00 \\
\hline
\end{tabular}

\subsection{Methods}

1. Ground water samples were collected from the bore wells using 0.751 plastic containers

2. The water samples were analyzed for various chemical parameters and compared with international water quality standard especially for agricultural uses.

\subsection{Evaluation of Quality of Water (Chemical Quality of Water Samples in the Laboratory)}

The ground water samples were collected from different parts of Federal University of Agriculture Makurdi campus. The parameters tested include hydrogen ion concentration $(\mathrm{pH})$, electrical conductivity $(\mathrm{EC})$, total hardness $(\mathrm{TH})$, total 
dissolved solids (TDS) and important cations such as calcium $\left(\mathrm{Ca}^{2+}\right)$, magnesium $\left(\mathrm{Mg}^{2+}\right)$, sodium $\left(\mathrm{Na}^{+}\right)$, potassium $\left(\mathrm{K}^{+}\right)$as well as anions such as carbonates $\left(\mathrm{CO}_{3}{ }^{2}\right)$, bicarbonates $\left(\mathrm{HCO}_{3}\right)$, chloride $(\mathrm{Cl})$, and sulphates $\left(\mathrm{SO}_{4}{ }^{2}\right)$ The $\mathrm{pH}$ and $\mathrm{EC}$ values were measured using a portable conductivity and $\mathrm{pH}$ meter. TDS were computed from EC multiplied by a factor $(0.55$ $0.75)$, depending on the relative concentration of ions.

Sodium and potassium were determined using flame photometer and, sulphate was analyzed spectrophotometrically. $\mathrm{TH}$, as $\mathrm{CaCO}_{3}, \mathrm{Ca}^{2+}$, $\mathrm{CO}_{3}{ }^{2}, \mathrm{HCO}_{3}$ and $\mathrm{Cl}$ were analysed using volumetric method. $\mathrm{Mg}^{2+}$ was calculated from $\mathrm{TH}$ and $\mathrm{Ca}^{2+}$ contents. The analysis was carried out in the Soil Science laboratory of University of Agriculture Makurdi. The results of the chemical analysis of the water samples were used to compare with the quality standard for various uses, especially for irrigation.

\section{RESULTS AND DISCUSSION}

\section{$3.1 \mathrm{pH}$}

Irrigation water can be classified as acid, neutral or alkaline, the acidity or alkalinity of irrigation water was expressed as $\mathrm{pH}(<7.0$ acidic; $>7.0$ basic). The normal $\mathrm{pH}$ range for irrigation water was between 6.50 and 8.40 . Abnormally low $\mathrm{pH}$ was not common in the study area, but may cause accelerated irrigation system corrosion where they occur. Therefore, the hydrogen ion concentration $(\mathrm{pH})$ of the samples varied from 6.3 to 7.6 (Table 6). From pH point of view the groundwater of the study area was safe and could be used for irrigation purpose.

In the study area, the TDS value varied from 64 to $747 \mathrm{ppm}$ (Table 6). Hence, high concentration of TDS in the water sample was due to the leaching of salts from soil surface and domestic sewage could have percolated into the groundwater, which lead to increased TDS values.

\subsection{Salinity Hazard}

Water with high salinity is toxic to plant and possess a salinity hazard. Soils with high levels of total salinity are called saline soils. High concentrations of salt in the soil can result in a physiological drought conditions. That is, even though the field appears to have plenty of moisture, the plant roots will be unable to absorb the water. Water salinity is usually measured by TDS (Total Dissolved Solids) or EC (Electric Conductivity). Total dissolved salt is sometimes referred to as the total salinity measured or expressed in parts per million (ppm), or in the equivalent units of milligrams per liter $(\mathrm{Mg} / \mathrm{L})$. Out of the analyzed five (5) groundwater samples, two (2) samples had an electrical conductivity values below $250 \mu \mathrm{s} / \mathrm{cm}$ and the other three (3) samples had an electrical conductivity ranging from 752 to $1516 \mu \mathrm{s} / \mathrm{cm}$. Therefore, based on electrical conductivity values, the groundwater analyzed in the study area was suitable for irrigation purpose. The first type groundwater could be used to irrigate almost all crops and soils. Very little salinity may develop which may require slight leaching; but it is permissible under normal irrigation practices except in soils of extremely low permeability. To achieve a full yield potential using the second type, selection of resistance crops and management alternatives were required.

\subsection{Sodium Hazard}

The irrigation water containing high proportions of sodium will increase the exchange of sodium content of the soil, affecting the soil permeability and the texture which makes the soil hard to plough and unsuitable for seedling emergence. The sodium/alkali hazard is typically expressed as sodium adsorption ratio. This index quantifies the proportion of $\mathrm{Na}^{+}$to $\mathrm{Ca}^{2+}$ and $\mathrm{Mg}^{2+}$ in a given water sample. When the concentration of $\mathrm{Na}^{+}$is high in irrigation water, it tends to be absorbed by clay particles displacing $\mathrm{Ca}^{2+}$ and $\mathrm{Mg}^{2+}$. This exchange process of $\mathrm{Na}^{+}$in water for $\mathrm{Ca}^{2+}$ and $\mathrm{Mg}^{2+}$ in soil reduces the permeability and eventually results in soil with poor internal drainage.

Irrigation water containing large amount of sodium is of a special concern due to effects on the soil and possess a sodium hazard. Sodium hazard is usually expressed as SAR or the sodium absorption ratio is calculated from the ratio of sodium to calcium and magnesium. The latter two ions are important since they tend to counter the effect of sodium. Continuous use of water having high SAR leads to breakdown of the physical structure of the soil. Sodium is adsorbed and becomes attached to the soil particles. The soil then becomes hard and compact when dried and increases its impermeability. 
Table 6. Descriptive results of the analyzed groundwater samples collected from different locations in the study area

\begin{tabular}{|c|c|c|c|c|c|c|c|c|c|c|c|c|c|c|}
\hline $\mathbf{S} / \mathbf{N}$ & Sample ID & $\mathrm{pH}$ & $\begin{array}{l}\text { EC } \\
(\mu s)\end{array}$ & $\begin{array}{l}\text { TDS } \\
\text { (ppm) }\end{array}$ & $\begin{array}{l}\mathrm{Na}^{+} \\
\end{array}$ & $\mathbf{K}^{+}$ & $\mathrm{Mg}^{2+}$ & $\mathrm{Ca}^{2+}$ & $\begin{array}{l}\text { TH } \\
\left(\mathrm{MgL}^{-}\right)\end{array}$ & $\mathrm{Cl}^{-}$ & $\mathrm{HCO}_{3}{ }^{-}$ & $\mathrm{CO}_{3}{ }^{2-}$ & $\mathrm{SO}_{4}{ }^{2-}$ & SAR \\
\hline 1. & CCL & 6.3 & 151 & 64 & $\overline{0.22}$ & $\overline{0.24}$ & $\overline{2.6}$ & $\overline{2.9}$ & 68 & $\overline{64}$ & $\overline{0.21}$ & $\overline{0.24}$ & $\overline{0.27}$ & 0.13 \\
\hline 2. & ANF & 6.4 & 236 & 117 & 0.24 & 0.26 & 2.8 & 3.1 & 76 & 66 & 0.18 & 0.21 & 0.23 & 0.11 \\
\hline 3. & UJM & 7.4 & 752 & 383 & 0.23 & 0.24 & 2.6 & 3.0 & 80 & 72 & 0.22 & 0.20 & 0.26 & 0.11 \\
\hline 4. & $\mathrm{PCH}$ & 7.6 & 1516 & 757 & 0.28 & 0.30 & 3.2 & 3.4 & 82 & 78 & 0.20 & 0.22 & 0.24 & 0.11 \\
\hline 5. & $\mathrm{CHP}$ & 7.6 & 1161 & 579 & 0.26 & 0.31 & 3.4 & 3.4 & 80 & 76 & 0.23 & 0.24 & 0.28 & 0.12 \\
\hline
\end{tabular}

KEY CCL: CHACHALINA, ANF: ANIMAL FARM, UJAM: UJAM COMMUNITY, PC H: PROTESTANT CHAPEL, CHP: CHIEFS PALACE

Table 7. Descriptive statistical result of the analyzed water samples from the study area

\begin{tabular}{|c|c|c|c|c|c|c|}
\hline Sample ID & Min & Max & Diff. between Max. and Min. & Mean & Standard deviation & Variance \\
\hline $\mathrm{pH}$ & 6.3 & 7.6 & 1.3 & 7.06 & 0.654 & 0.428 \\
\hline $\mathrm{EC}$ & 151 & 1516 & 1365 & 763.2 & 586.9 & 344452 \\
\hline TDS & 64 & 757 & 693 & 380 & 296.1 & 87691 \\
\hline $\mathrm{Na}^{+}\left(\mathrm{MgL}^{-}\right)$ & 0.22 & 0.28 & 0.06 & 0.246 & 0.0241 & 0.00058 \\
\hline $\mathrm{K}^{+}\left(\mathrm{MgL}^{-}\right)$ & 0.24 & 0.31 & 0.07 & 0.27 & 0.0332 & 0.0011 \\
\hline $\mathrm{Mg}^{2+}\left(\mathrm{MgL}^{-}\right)$ & 2.6 & 3.4 & 0.8 & 2.92 & 0.363 & 0.132 \\
\hline $\mathrm{Ca}^{2+}\left(\mathrm{MgL}^{-}\right)$ & 2.9 & 3.4 & 0.5 & 3.16 & 0.230 & 0.053 \\
\hline $\mathrm{TH}\left(\mathrm{MgL}^{-}\right)$ & 68 & 82 & 14 & 77.2 & 5.586 & 31.2 \\
\hline $\mathrm{Cl}^{-}\left(\mathrm{MgL}^{-}\right)$ & 64 & 78 & 14 & 71.2 & 6.099 & 37.2 \\
\hline $\mathrm{HCO}_{3}^{-}\left(\mathrm{MgL}^{-}\right)$ & 0.18 & 0.23 & 0.05 & 0.208 & 0.0192 & 0.00037 \\
\hline $\mathrm{CO}_{3}{ }^{2-}\left(\mathrm{MgL}^{-}\right)$ & 0.20 & 0.24 & 0.04 & 0.222 & 0.0179 & 0.00032 \\
\hline $\mathrm{SO}_{4}{ }^{2-}\left(\mathrm{MgL}^{-}\right)$ & 0.23 & 0.28 & 0.05 & 0.256 & 0.0207 & 0.00043 \\
\hline
\end{tabular}


SAR can be estimated by the formula

$$
\mathrm{SAR}=\frac{\mathrm{Na}^{+}}{\sqrt{\frac{\mathrm{Ca}^{2+}+\mathrm{Mg}^{2+}}{2}}}
$$

\subsection{Chloride}

Chloride contribute to salinity of irrigation water, and when concentrations are high enough, can be toxic to plants, tough grasses are not particularly sensitive to chloride and can tolerate levels up to $100 \mathrm{mg} / \mathrm{L}$. Tough grasses can sustain injury when irrigated with water containing $>355 \mathrm{mg} / \mathrm{L}$ of chloride. Tough grasses manager should be aware that some ornamental plants are sensitive to chloride concentrations above $70 \mathrm{mg} / \mathrm{L}$.

\subsection{Miscellaneous Problems}

Bicarbonate, although not ordinarily thought to be a toxic ion, was reported to cause zinc deficiency in rice. According to Mikkelson [16], bicarbonate in excess of $2 \mathrm{meq} / \mathrm{l}$ in the water used for flooding and growing paddy rice is reported to cause severe zinc deficiency. Actual zinc of 8 to $10 \mathrm{Kg} / \mathrm{ha}$ from zinc oxide or zinc sulfate is surface applied to remain in the upper 5 to $10 \mathrm{~cm}$ of soil [16].

Nitrogen $\left(\mathrm{NO}_{3}-\mathrm{N}\right)$ in the applied irrigation water is generally beneficial to most crops but may cause problems for some. Nitrogen in the irrigation water is readily available and if present should be considered as an important part of the fertilizer program. For most crops, this nitrogen is equivalent to fertilizer nitrogen and should be included in the total nitrogen planned for applications. For a few crops, however, the added nitrogen from the water may be too much and results in excessive and vigorous growth, delayed or uneven maturity, and reduced quality. These sensitive crops include apricots, grapes, sugar beets and cotton, but there are probably others.

\section{CONCLUSION}

The physical and chemical parameters of the samples were evaluated to determine groundwater quality for irrigation purpose. The result showed maximum and minimum values for electrical conductivity (EC) and total dissolved solids (TDS). According to the results, $\mathrm{pH}$ values in the study area (6.3-7.6) indicated that the water was suitable for irrigation since, the normal $\mathrm{pH}$ range for irrigation water is 6.5-8.4. According to EC values and also FAO guidelines for irrigation water, the result showed that the groundwater EC ranged from $<250$ to 1516 indicating that, the water was of medium salinity. The result further showed that sodium adsorption ration (SAR) was regarded as adequate as the values were less than $1.0 \mathrm{meq} / \mathrm{l}$ indicating that, the water had low sodium hazard. The major cation and anion in the groundwater were $\mathrm{Na}^{+}$ and $\mathrm{Cl}^{-}$, which demanded special management for controlling salinity and sodium hazard at the study area.

Generally, the groundwater in the study area, as assessed was discovered to be suitable for irrigation and other agricultural purposes. However, in order to achieve and sustain full yield potential for a long period of time, and to avoid increase in salinity and avoid the occurrence of sodicity and toxicity hazards in future, proper irrigation scheme is required in the form of crop selection, fertilizer usage and suitable alternative management practices. Therefore, going by the results obtained from the analysis, the groundwater in the study area was safe or suitable for irrigation purpose.

\section{COMPETING INTERESTS}

Authors have declared that no competing interests exist.

\section{REFERENCES}

1. Garduno H, Foster S. Sustainable groundwater irrigation - approaches to reconciling demand with resources. World Bank/GWP GW-MATE Strategic Overview Series SO-4 (Washington DC, USA); 2010.

2. Fasina AS, Awe GO, Aruleba JO. Irrigation suitability evaluation and crop yield-An example with Amaranthus cruentus in Southwestern Nigeria. Ekiti State, Nigeria; 2008.

Available:http://www.academicjournals.org/ AJPS

3. Nata T. Surface waters potential of the Hantebet basin, Tigray, Northern Euthopia. Agricultural Engineering International: CIGR E-journal, Manuscript LW 05010. 2006;8.

4. Narsimha A, Sudarshan $V$, Srinivasula $P$, Vishnu B, Ramana Kumar M, Niranjan Kumar S. Water Research Development. 2012;2(3):68-75.

5. Bohn HL, Brain LM, George AO. Soil chemistry. John Wiley \& Sons, 2nd Edition, New York; 1985. 
6. Food and Agriculture Organization (FAO). Guideline for land evaluation for irrigated agriculture. Soils Bulletin, 55. FAO, Rome; 1985.

7. Brady NC, Weil RR. The nature and properties of soils. $13^{\text {th }}$ Ed. Prentice Hall, NJ; 2001.

8. Callow RC, Robins NS, MacDonald AM, MacDonald DMJ, Gibbs BR, Orpen WRG, Mtembezeka P, Andrews AJ, Appiah SO. Groundwater management in drought prone areas of Africa. International Journal of Water Resources Development. 1997;13(2):241-261.

9. UNEP. Groundwater a threatened resource. UNEP, Nairobi (UNEP Environmental Library No15); 1996.

10. Igomu EA, Idoga S. Evaluation of soils for cowpea (Vigna unguiculata L.) production: A case study of siwes farms of University of Agriculture Makurdi. IJPSS. 2017;15(3): 1-8.

11. Ojanuga AG, Ekwoanya MA. Temperal changes in land use patern in Benue River flood plain and adjoining uplands at
Makurdi, Nigeria. In: L. Theombiano maintaining soils in the environment with remote sensing and proceeding of the ISSS International Symposium Onagadongon Burkina Faso. 1995;418.

12. Longenecker DE, Lyerly PJ. Control of soluble salt in farming and gardening. Texas Agricultural Experiment Station, Texas A \& M University System, College Station. 1974;B-876:36.

13. World Health Organization (WHO). Guidelines for the safe use of groundwater and excreta in agriculture and aquaculture. Executive Summary; 1971.

14. Food and Agriculture Organization (FAO). Water quality for agriculture, R. So Ayers and D. W. Escort. Irrigation and Drainage Paper 29, Rev. 1. Rome. 1985;174.

15. Richards LA. Diagnosis and improvement of saline and alkali soil. US Department of Agriculture, Agri. Hand Book 60, Washington; 1954.

16. Food and Agriculture Organization (FAO). Water quality for agriculture. FAO, Rome; 1989.

(C) 2017 Odoemena et al.; This is an Open Access article distributed under the terms of the Creative Commons Attribution License (http://creativecommons.org/licenses/by/4.0), which permits unrestricted use, distribution, and reproduction in any medium, provided the original work is properly cited.

Peer-review history:

The peer review history for this paper can be accessed here: http://sciencedomain.org/review-history/20061 